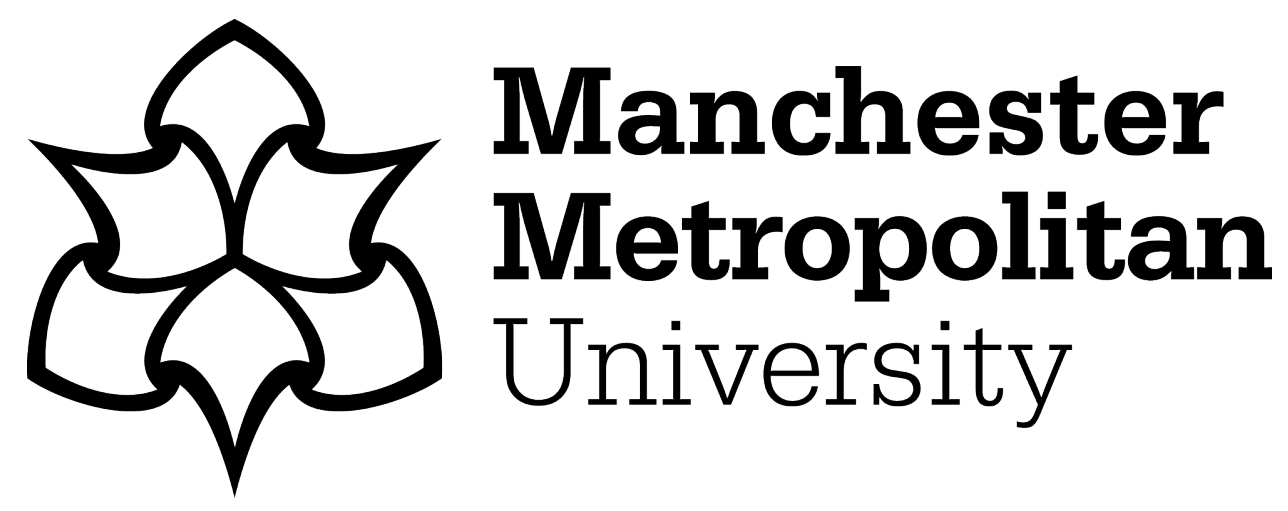

Lou, Eric CW ORCID logoORCID: https://orcid.org/0000-0001-7099-1426, Lee, Angela and Goulding, Jack (2020) E-readiness in construction (ERiC): self-assessment framework for UK small and medium enterprise building services providers. Architectural Engineering and Design Management, 16 (1). pp. 3-22. ISSN 1745-2007

Downloaded from: https://e-space.mmu.ac.uk/623031/

Version: Accepted Version

Publisher: Taylor \& Francis

DOI: https://doi.org/10.1080/17452007.2019.1617669

Please cite the published version 


\title{
E-Readiness in Construction (ERiC): \\ Self-Assessment Framework for UK Small and Medium Enterprise Building Services Providers
}

\author{
Eric C.W. Lou ${ }^{1 \wedge}$, Angela Lee ${ }^{2}$, Jack Goulding ${ }^{3}$ \\ $1^{\wedge}$ School of Engineering, John Dalton Building, Manchester Metropolitan University, \\ M15 6BH Manchester, UK. \\ e.lou@mmu.ac.uk \\ ${ }^{2}$ School of the Built Environment, Maxwell Building, University of Salford, M5 4WT \\ Salford, UK. \\ a.lee8@salford.ac.uk
}

${ }^{3}$ School of Architecture and the Built Environment, Faculty of Science and Engineering, University of Wolverhampton, WV1 1LY Wolverhampton, UK. j.goulding@wlv.ac.uk 


\begin{abstract}
The construction industry's ability to innovate in order to improve its practices has been widely debated. As organisations in other sectors globally are addressing technology challenges, is the UK construction industry e-ready? Of particular concern is the plethora of small and medium enterprises (SME) that constitute over $80 \%$ of the UK construction industry. There are noticeable SME laggards in the uptake of new processes and technologies. This paper aims to assess the e-readiness levels of UK SME building services provider in order to leverage the advantages of technology opportunities in the future. The resultant self-assessment ERiC framework enables SMEs to quantify and measure ereadiness from an organisation, technical and process perspective.
\end{abstract}

\title{
Keywords
}

e-readiness; construction; Small and Medium Enterprise; building services providers 


\section{Introduction}

The UK construction industry needs to improve its practices as it has been ongoingly criticised for its less than optimal performance since the 1940 s by several government and institutional reports such as Simon (1944), Emmerson (1962), Banwell (1964), Latham (1994), Egan (1998) and Fairclough (2002). The majority of these reports conclude, time and time again, that the fragmented nature of the industry, lack of co-ordination and communication between parties, the informal and unstructured learning processes, adversarial contractual relationships and lack of customer focus is what inhibits the industry's performance. Egan (1998) purported: ' ....there is a deep concern that the industry as a whole is under-achieving.' Construction projects are also often seen as unpredictable in terms of delivery time, cost, profitability and quality, and in addition, investment into research and development is usually seen as expensive when compared to other industries (Xia et al., 2018). The repeated critique of all of these reports thus questions the ability of the construction industry to innovate and manage change to improve its practices (Gambatese and Hallowell, 2011). Furthermore, the image of construction is rather 'bleak' as it struggles to address these ongoing challenges. According to Howell (1999), the 'inefficiency' of the construction industry has tended to be the way of life. This may be due to the fact that none of the reports have been significantly acted upon. As Latham (1994) points out '...some of the recommendations of the reports were implemented ... but other problems persisted, and to this day, even the structure of the industry and nature of many of its clients has not changed dramatically.' This stance remains presently in 2019. So, is change in the industry's structure plausible or even appropriate to bring about widespread improvement or innovation?

This paper argues that the UK construction industry must change. Organisations in differing sectors are moving ahead in terms of harness the benefits of IT (Fortune, 2018). The UK government released the Government Construction Strategy that sets out a vision of how the country could lead the way in global construction over the next 10 years (HM Government, 2013). Among other aspirations, the strategy aims for a 'smart' UK construction industry by 2025 that is efficient and technologically advanced. However, there was no detail provided on how the industry could achieve this; e-readiness refers to a country's capacity and state of preparedness of information technology (IT) infrastructure and its ability for sustainable development. Organisations within the construction industry have heavily invested in IT, the result of which has led to a level of innovation and business improvement. Whilst it can be argued that the industry's main functions and processes are still relatively unchanged, there has been a real challenge to improve performance and reduce costs using IT as the lever of change (Olawumi and Chan, 2018). However, efforts have often been hampered due to several barriers, not least the industry's structure, the fragmented supply chain, lack of investment in IT, and limited IT 'champions' who are able to understand IT-based innovation challenges and have the support and empowerment of senior decision makers within the organisation to sanction, augment, and drive forward this change particular for small and medium enterprises (SME), which make-up a vast proportion of the industry (BIS, 2013). To address these issues, this research aims assess the e-readiness levels of UK SME building services providers in order to leverage the advantages of technology opportunities in the future. A proposed new e-readiness self-assessment framework for construction SMEs from the findings of 
critical success factors pertinent to the UK construction sector as a means to provide guidance for the industry at large, this will enable organisations to enter new markets - aware of both the revenue potential and the possible bottlenecks to development.

\section{$\underline{\text { UK Construction Industry and SMES }}$}

The UK Construction Industry is the country's third largest employer, with a 2.9 million workforce and accounting for approximately 10\% of employment in 2014 (Anwyl, 2017). Recent data from the first quarter of 2014 showed that the private sector contributed more than $74 \%$ of construction output. Housing and commercial projects let the way with a combination of $56 \%$ of the total value (Rhodes, 2014). The scale of small organisation activity in the UK construction industry is considerable, with in 2014, accounting to 40\% of GDP and is a major contributor to local economies (BIS, 2013). This paper will adopt the European Commission's definition of SME, whereby micro enterprises represent 0-9 employees, small enterprises represent 10-49 employees, and medium enterprises represent 50-249 employees, with the exception of agriculture, hunting, forestry and fishing organisations. According to Robbins et al. (2000), SMEs are important to the economic vitality of cities, states and countries due to their significant number and employees. However, they tend to display vulnerability in facing up to various conditions prevailing in a country's economy resulting in business failure. The ability of SMEs to turnaround their organisation is often constrained due to limited access to financial resources and capital (Wong et al., 2018). Historically, it has been recognised that the SME sector poses various challenges for implementing policies, transfer of good practice and various Government agendas strategic horizons and organisational capabilities of SMEs do not allow sufficient 'organisational slack' to conduct activities outside their main business activities (Sexton and Barrett, 2003). Further, the fragmented and diverse nature of the industry illustrates the inconsistent level of IT among organisations in the construction industry. Current practice indicates that the implementation of IT is undertaken on an ad-hoc basis and there is no formalisation of IT into mainstream business activities. It is therefore pertinent to investigate the e-readiness of SMEs in adopting and embracing IT.

Specifically, there is no strategy on how organisations could be e-ready or how to harness the power of IT. The UK National Federation of Builders (NFB, 2012) reported on the readiness of organisations to adopt Building Information Modelling (BIM) confirms that the industry is not ready to achieve BIM Level 3 as set out in the Government Construction Strategy. Findings demonstrated high interested in BIM and accepted that BIM will be central importance to the organisation, but only $10 \%$ of SMEs are planning to invest in training.

\section{E-readiness}

IT holds tremendous potential for improving construction businesses. While the industry is facing globalisation and an expanded knowledge-based economy, the capability of IT is undeniable for achieving competitive advantage. Understanding e-readiness enables organisations to enter new 
markets: be aware of both the revenue potential and the possible bottlenecks to growth. The notion of e-readiness means different things to different people, in different contexts, and for different purposes (Lou and Goulding, 2010). As a result, a gap exists between ideas and concepts on the one hand, and the practical applications and implications on the other (bridges.org, 2017). In spite of all the differences in definitions and opinions, this research takes the position of e-readiness 'as a measure of the degree to which an organisation may be ready, prepared or willing to obtain benefits which arise from the digital economy'. E-readiness research is fragmented, diverse, not specifically targeted for the construction industry, and is not designed for organisational issues; while organisational e-readiness is still very much in its infancy with only four known academic organisation-based readiness tools available BEACON (Khalfan et al., 2001), VERDICT (Ruikar et al.,2006), GPIS/NICE (Salah, 2003), BIM Maturity Matrix (Succar, 2009) and Technology Readiness Levels (TRL) (Banke, 2017). BEACON has the ability to assess the readiness state of the organisation, but is unable to provide steps or methods to improve. There is no given 'how to' guide to progress and be better. The organisation also does not have the option to priorities factors they deem to be more important. Similarly, VERDICT is unable to provide methods for the organisation to improve. This tool is rigid and does not allow any weighting systems to be deployed, therefore, users could not prioritise any factors shall they want to. The GPIS/NCIE tool is not industry specific and it recommends that the model to be conducted by technology experts that are experienced in that particular industry. The BIM Maturity Matrix is considered as the closest model for e-readiness for organisation. However, this is designed especially for the uptake of BIM for organization and it does not have the provision to be customised. The Technology Readiness Levels is an industrywide maturity level index and not designed for the construction industry, let alone SMEs in the industry. With the unavailability of a specific e-readiness tools for SMEs in the industry, there is a need for such a framework to guide construction organisation to be ready to harness the full potential of their current and future IT system(s).

The rubrics to access the critical success factors of e-readiness for construction SME organisations started with the identification of people, process and technology themes (Lou and Goulding, 2010), and ranking of the five key e-readiness enablers (Goulding and Lou, 2013). This paper will further refine the five key enablers to general CSF through case studies and organisational observations.

- Leadership and Empowerment (People)

- Change Management (People)

- Business and Information Process (Process)

- Policy/Strategy/Vision (Process)

- ICT Sharability/Interoperability (Technology)

The role of senior management to support the development of an e-society on the organisational level is crucial to as to 'set an example' for other to follow, both within and outside the organisation. Leadership plays a vital role in directing efforts towards success. The importance of leadership stems from its role in providing a clear vision of the future, communicating the vision, being able to involve other people in the implementation efforts, being prepared to provide sufficient commitments to the 
overall efforts and bearing the ability to motivate people rather than directly guiding them. The need to change is usually driven by external factors such as new legislation or increased competition, or internal factors such as the implementation of new technologies. Literature further describes various types of change - crisis change, chosen change, developmental change, transitional change and transformational change (Margherita and Petti, 2010). Understanding the organisation's business and information process is critical for the success of any new changes in the organisation (Berente et al., 2009). The existence of an effective communication and information process reflects transparency and predictability of regulatory implementation, openness of organisational policies and (political and business) stability of the organisation (Halabi et al., 2017). Mulcahy (1990) observes: to be successful, a construction organisation must have clear objectives recognising the markets it wishes to address, services it wishes to provide, risk it may carry, structure its use, the environment it operates within, controls it put in place, and the returns it wishes to achieve. To successfully achieve them, the organisation needs to have a fitting structure, on-going communication, a team of skilled and motivated people and a culture for performance and satisfaction. IT has progress immensely in the past years from a stand-alone individual machine to mass-market product openly used by all. This drives the need for IT hardware and software to 'talk' and be compatible to each other, and ultimately embed our everyday action with IT (Lou and Alshawi, 2009). In this context, IT sharabillity and interoperability is being increasingly used to support business strategies as an enabler to leverage its potential to gain a competitive advantage and therefore new markets and clients. The potential e-readiness critical success factors from the literature are as listed in Table 1.

[insert Table 1]

\section{Research Methodology}

This research builds on previous work conducted by Goulding and Lou (2013), where five e-readiness enablers were identified. To further this research, a mixed approach methodology of case studies, organisational observations and expert validation is used. Three case studies were conducted with selected SME organisations based in the UK. Organisations were selected based on their structure and capacity as an SME, registered in the UK with expertise as a building service provider - and not their IT capability. A minimum of three personnel was interviewed for each case study, including a senior manager, a technical (IT) representative and a member of the operations team (construction/service). Additional discussions were also held informally with other employees whilst on-site. Interviewees were questioned on the five e-readiness enablers and the ten potential sub-enablers for each key-indicator (Table 1). The differing representatives from each organisation were to provide a holistic overview on the organisation, and the thoughts from the different departments. Results from the case studies will be analysed for the production of the e-readiness framework. From the three case studies conducted, nine

dedicated semi-structured interview sessions were carried out with representatives from differing departments/ organisational hierarchy; they were subsequently followed by six informal discussions 
and observations with other members within each case study organisation. It is evident from the findings that every organisation behaves differently, have differing business priorities and different internal process.

An e-readiness framework will be proposed based on the concepts of maturity modelling, where the maturity concept is based on the notion that a distinction could be made in regard to levels of maturity of organisations based on pre-set characteristics. It provides a step-by-step guide and explains the incremental readiness levels for executives to evaluate their business holistically in order to secure ereadiness best practice. This can also be used to undertake benchmarking exercises in order to position themselves in the marketplace; to demonstrate their past, current and future situation. This framework will be evaluated and validated through the 'parallel-forms' reliability process to ensure credibility and confirmability of data collected from the case studies and framework content objectivity.

\section{Case Studies}

Case Study 1 (CS1) is a real estate services provider is in the process of developing international networks of offices worldwide, offering a broad range of specialist advisory, management and transactional services. The organisation wants to be e-ready, but do not know how and have not tools to do so. Staffs are open for changes and are willing to learn more and are awaiting leadership from senior management. To ensure e-readiness practices are warranted within the organisation, there must be a clear vision or policy from senior management; and this must be filtered down to all staff, or this practice will remain a paper document sat on the shelf. A well-written vision/policy must derive from the analysis, understanding and appreciation within the organisation and external forces - foresight is critical; this will then be able to empower individuals and groups to achieve further in the right direction.

Case Study 2 (CS2) is a leading specialist in property design, fit-out, refurbishment and maintenance services provider. CS2 has in excess of 1,000 projects conceived and successfully delivered throughout the UK, working in over 100 different towns and cities but communication between the site offices and head office is very poor. Another issue is the accessibility to the most up-to-date data and work files as there is no direct connection to the head office, there are always discrepancy on the most recent files to be used. This case study presented a thought-provoking insight to an organisation that has a failed IT system and is now in the process of creating another. This demonstrated that the organisation and the senior management understand that IT is an integral element in the organisation for it to continuously grow. With business expansions anticipated for the Middle East, CS2 has no option but to invest in its IT system. This system is carefully planned, designed and programmed to meet internal and external needs and requirements. Change management within the organisation is a crucial element to manage any future changes, perception and expectation.

Case Study 3 (CS3) is a privately-owned property solutions business, employing over 150 people who work on sites and offices. The organisation is undergoing change in all departments and there is a 
sense of urgency to improve internal processes, negotiate external IT responsibilities with clients and taking the business forward with IT. All interviewees agree that The Board understands, appreciates and acknowledges the benefits of IT, but there is little investments or improvements to the current system. However, there was a conflict of interest as the employees feel that IT is at its minimum and there is incentive for The Board to further improve or invest. It is clear that the organisation's IT strategy in place but it is often neglected or unknown, as it is not integrated or tied to other organisational strategies. The rubrics for the organisation to change are in place; only The Board are to be convinced to make the investments.

Throughout the case studies, there were no objections or addition towards the five pre-defined key indicators. Data collected is compiled into Table 2, where each Case Study involved three separate interview sessions (eg CSx-C1, CSx-C2, CSx-C3) and one informal interview session with members of the organisation (eg. CSx-IF). The understanding of the term 'e-readiness' brought a whole new phenomenon, as different people understand it varying ways. Data collected from different individuals with different responsibilities showed that the understanding gap could not be wider - evidence from role of the interviewees (management, technical and operational), as shown in Table 3.

[insert table 2 here]

[insert table 3 here]

The leadership and empowerment key indicator were mentioned in every case study, and in particular in CS2 and CS3. CS3 highlighted that the senior management was unsure of readiness, hence withholding further investment, while the CS2 emphasised the importance of leadership to bounce back from a poor IT experience. From the data collected, the three highest frequencies mentioned were: Foresight/Vision, Improve and Inspire.

Business and Information Process represents the inner-operations of the organisation. This explains the process of how tasks are expected to be completed by whom, what means, when to completed and to whom it is responsible to - the process is especially critical for larger organisation due to the large number of staff and geographic spread. This is also to enable process automation, system integration and data exchange/ interchange. CS1 and CS2 indicated the importance of a process mapping and documentation through a Quality Management System or similar, to ensure process standardisation and to make information available to all. The critical success factors (CFSs) were Automation, Data exchange/ Interchange and Standards.

IT sharabillity/interoperability is topical among the technical staff interviewees, and quite appropriately so. The only method to encourage uptake or usage of the IT systems is to ensure seamlessness between different systems and software - to ensure they 'talk' to each other. Discussions also led towards the availability of internationally accepted standards (e.g. ISO, EU, BS, etc.) towards system 
development, technical knowledge towards the standards and the availability of system sources (e.g. coding, development toolkits, etc.). Another cause for concern is the legality of the IT system/software (e.g. open source, proprietary, etc.) and the complication of data sharing (e.g. BIM, extranets, etc.). Most importantly, senior management must understand the technical and management of IT systems/software is a major issue for the industry as a whole. Access/Uptake, Legal Framework and Standards were identified as CSFs.

The issue of change was particularly heightened in CS1, where staffs were ready to change, willing to learn more and open to new experiences, but they did not know how to proceed. This shows that change management is more than culture; it is about the organisation's willingness to improve as a collective unit from all levels in the organisation. Data reported CSF of strategy/strategic framework, interaction/communication and support/executive sponsorship for change management. This is evidence from the necessity of a change management strategic framework in place, an integrated implementation plan, well-documented business process, executive sponsorship and well communicated to all staff.

All case study organisations investigated are looking into the future and have the vision of using IT to expand their business to have competitive advantage. Organisational foresight is essential as a tool to integrate organisational strategy and action plans. The key to achieving forward planning is for the organisation to identify 'what they want to achieve' and involve staff in the planning process. This will in turn empower staff to improve themselves to meet the challenges (that they help to plan) in the future, which was heavily evidenced from CS3. Also, the appetite in learning, experimenting and predicting future technologies is seen as important. CSFs were identified as policy/ strategy/vision were foresight, inspiration/ empowerment and new technologies. The findings from the case studies are thus presented in Table 3. Although the 5 key CSFs pertinent in the literature (see Table 1) of: leadership and empowerment; change management; business and information process; policy/strategy/vision; and IT sharabillity/interoperability; their application in the construction sector has circumvented differing issues that are pertinent to construction. Findings of the case studies have been used to inform the development of an e-readiness framework.

\section{Framework development}

The development of an e-readiness in construction (ERiC) framework is based on maturity modelling concept and will incorporate key indicators (KI) and sub-key indicators (SK) as part of a self-assessment framework specifically for building services providers SMEs. Maturity levels show a sequential development, from an initial level with basic requirements (Level 1), through to a maximum maturity level (Level 5), categorised as the optimum performance level. The operationalisation of this approach follows the principles of Sarshar et al. (2004), where progression from one level to the next represents a step change in maturity. In this respect, organisations in Level 5 are classified as "Future proof"; at 
Level 4 “Advanced Level", Level 3 "Intermediate Level”, Level 2 "Low Level”, and at Level 1 "Unprepared". Issues addressed by large organisations and SMEs in construction varies despite being in the same industry (Jamieson et al., 2013). This framework provides a step-by-step guide for the user to evaluate their business holistically in order to secure e-readiness best practice.

The framework then calculates and presents a final score to the user. To obtain a better assessment of the organisation, the framework administrator may choose a few users to complete the framework and take an average score. The ultimate goal of this framework is to provide the administrator/ user with a score - this can be used to undertake benchmarking exercises in order to position themselves in the marketplace. The framework will also be able to assist user in identifying 'the next course of action' to improve their e-readiness stature. Sample cases were created to assist users to understand the maturity statements; sample cases are described to provide the most accurate scenario for each statement. Each case evolves around IT application, software, technology or general management related scenarios.

A scoring system provide the users with a tangible figure or number for benchmarking. ERiC carries a final score of $100 \%$, of which, two scoring system is proposed, and the framework user or administrator have to options to user either Tier 1 or Tier 2 scoring, or both at the same time. Tier 1 scoring consist of weightings for five $\mathrm{KI}$ only and Tier 2 scoring represents the twenty-five SKs. Each Tier must be scored to a total of $100 \%$ respectively. The choice of going into the details or simply to stretch the surface is in the hands of the assessor. Senior Management (CEOs, COOs, Directors, etc.) may opt for the more Tier 1 scoring, while managers and operational staff (IT Managers, Business Managers, etc.) may select Tier 2 scoring. Sample scoring systems are presented in Table 4 and Table 5.

\section{Leadership and Empowerment (KI1)}

The leadership and empowerment key indicator were mentioned in every case study, and is echoed throughout literature review. Leadership plays a vital role in directing efforts towards success and stems from its role in providing a clear vision of the future, communicating the vision, being able to involve other people in the implementation efforts, being prepared to provide sufficient commitments to the overall efforts and bearing the ability to motivate people rather than directly guiding them.

Foresight/Vision (SK1.1): Organisations must have a vision to move forward - forward thinking vision for technology to support and enhance organisational aims in terms of supporting the administration, management, employees and the wider built environment industry (Sarros et al., 2011). The highest level of maturity in IT vision reflects a world-leader in providing ideas, forward thinking and continuous improvement; through extensive research and development done within the organisation, and often hailed the as a global champion; while the lowest level will see Senior Management with no concern in improving current work practice and/or no interest joining the digital economy but maintaining a paper intensive organisation.

Involve (SK1.2): High-involvement leaders view employees at all levels as true partners - such practices allow the organisation to tap into the creativity and energy of their employees to an 
extent that is not possible with traditional forms of management (Randel at el., 2018). Highinvolvement leaders will require efficient and accurate methods of communication for successful partnerships with colleagues and employees, thus, boosting productivity of the business.

Inspire (SK1.3): The ability to inspire people to reach great heights of performance and success passion, purpose, listening and meaning help make a leader inspirational. Inspired leaders will rub off inspiration to their employees, to continuously improve and develop in their responsibilities, which in turn employees will give their enthusiasm and commitment to achieve organisational goals (Murnieks et al., 2016). The ability of the leaders to deliver inspirational speeches or delivery personal success stories has its impact on employees - and this also reflects leadership by example.

Integrity (SK1.4): Leaders with strong integrity are demonstrated through their strength of character - walking the talk, doing what was promised - authentic, straightforward, open, honest and direct in their dealings with others. A leader's personal integrity will indirectly represent the organisation, to be respected by employees and the public or otherwise. Integrity speaks for itself and will directly reflect on the leaders' action and decision. Employees in return will be more approachable and will be more willing to accept critics (as positive feedback) and will always try to improve (Bazzy and Woehr, 2017).

Improve (SK1.5): Improvement, to change for the better. Continually increasing the effectiveness and/or efficiency of the organisation, to fulfil its policies and objectives with a focus satisfaction. Leading and empowering employees is critical as they will need to absorb, understand and execute the organisational values and goals in the best possible manner, and in the same time to improve themselves. Personal improvement could only come when the employee welcomes change (Lou and Alshawi, 2009).

\section{Change Management (KI2)}

Organisations, large and small, need to change and develop if they are to remain competitive and satisfy clients' ever-increasing expectations. The need to change is usually driven by external factors such as new legislation or increased competition, or internal factors such as the implementation of new technologies.

Strategy/Strategic Framework (SK2.1): A strategic framework allows the organisation and its supply chain to create a roadmap for change. This will drive the change process from the highest level (vision, goals and objectives) to the day-to-day work. Implementation is the essence of how change management could be successful in organisations (Ahuja et al., 2010). With a strategic framework in place, Senior Management will be able to lead in accordance to the framework and staff will know the process and the anticipated goal.

Implementation (SK2.2): Implementation is the essence of how change management could be successful in organisations in activities such as change management development and deployment, techniques, project management, organisational resources, managerial style, communication and coordination (Margherita and Petti, 2010). Successful change management 
requires a large commitment from Top Management, to provide leadership, support and resources - to champion the cause for change.

Support/Executive Sponsorship (SK2.3): The role of the executive sponsor is not only critical to the success of each project but also critical to successful delivery of beneficial outcomes and for feeding that information back to the executive and to portfolio management (Lee et al., 2011). At times, the attendance of the Senior Management demonstrates their commitment to change, indicating that 'we are all in this together', and will inspire employees to achieve and do more.

Practice (SK2.4): Business practice management is the collection of activities that corresponds to the planning and observing the effectiveness of a certain construction business process, method, or solution. In adapting change, current business practices must support business needs - every practice should be 'correct first time', provide value-added services, supporting organisational vision and strategies (Amalia and Nugroho, 2011).

Interaction/Communication (SK2.5): The primary aim of communications in any change programme is to develop support for the foreseeable changes as part of the organisational change programme, providing the changes to be successfully implemented, conveying change means getting employees to change their way of thinking, their way of working or their way of completing tasks, and this change could only take place with the employee (Fox, 2011). To facilitate this, the communication aspect is of the highest importance and targeted at key employees whom could really make a change. This could be dealt more effectively if strategic change management communication is established from the start of the project.

\section{Business \& Information Process (KI3)}

This represents the inner-operations of the organisation, the lifeline of the organisation. This explains how things are done, what to be done, when to do it, where to do it, why to do it and who is responsible? This enables process automation, system integration and data interchange. Understanding the organisation's business and information process is critical for the success of any new changes in the organisation.

Access/Availability (SK3.1): The availability, formalisation and documentation of business and information process enable employees to comply with a standard set of repeatable work process to ensure a smooth and congruent business processes, as well as capturing organisational knowledge. This is demonstrated by having data, applications and systems working exactly as they should, as and when it is needed (Bacic and Fadlalla, 2016).

Automation (SK3.2): This illustrates the degree of human component that could be removed from the organisational business and information processes. Highly matured organisations have their business and information automated, where these can be captured by external stakeholders and supply chain. The repeatability of the process is also reinforced with valueadded services as the process improves through time (Samaranayake, 2009).

Data Exchange/Interchange (SK3.3): The interchange of information and data, through structured business processes and seamless data transaction, feeds into organisational intelligence for 
management to make their informed decisions (Rainer and Cegielski, 2011). The lowest level of maturity indicates the organisation has no process or data interchange in the organisation; different individuals in the organisation own different information.

External Parties/Integration (SK3.4): The capability of the organisation to connect people, tasks and information with disparate technology or systems - to streamline the transfer of business information to and from various technology resources. Berente et al. (2009) describes integrated business process as 'one in which the effort associated with information flows between activities is minimised, and business process integration describes the practices associated with the minimisation of this effort, or the tighter coupling of organisational activities in a business process'.

Standards (SK3.5): This factor examines to what extent business and information process standards (international and national) and methods are used in the organisation. Standards are essential to provide a guideline and guidance for best practice; and in this case, to provide a standard platform for business and information exchange (Succar, 2009).

\section{Policy/Strategy/Vision (KI4)}

All organisations involved with the interviews are looking into the future and have the vision of using IT to expand its business and have competitive advantage. Organisational foresight is essential as a tool to integrate organisational strategy and action plans. The key to achieving forward planning is for the organisation to identify 'what they want to achieve' and involve staff in the planning process. This will in turn empower staff to improve themselves to meet the challenges (that they help to plan) in the future. Dissemination/Involvement (SK4.1): The involvement and engagement of employees in the creation of policy/strategy/vision provides the sense of belonging and ownership to employees in the organisation. This involvement must filter and engage employees at all levels dissemination to every department, project team and the supply chain - to enable employees to understand their role, responsibility and importance to the organisation's success (Parida and Kumar, 2006).

Foresight (SK4.2): Organisational foresight provides futures planning and looking into potential risks - this could only be done through an in-depth understanding of its business and industry, technology and culture of the organisation. Foresighting is especially essential as organisational IT investment could be front-loaded and benefits could only be visible in the long run (Misuraca et al., 2010).

Inspiration/Empowerment (SK4.3): Leaders could continually empower employees through demonstrating the true value of intellectual capital with employees; sharing leadership vision; communicate organisational goals and direction; putting trust on employees; providing the best information for decision making; inspiration for all; delegating authority and impact opportunities to employees; and to provide frequent feedback (regardless if is positive or negative) (Mansell, 2010)

New Technologies (SK4.4): The vision of new technologies is essential for organisations to plan for IT investments, provisions of maintenance and to research into prospecting technologies. 
To achieve this, the organisation will need to blend two major sets of technical and management capabilities. Firstly, it is important for the organisation to understand the capability organisational IT, understanding current capacity and the needs of the organisation in the future. Secondly, the organisation must set targets for technology research, development and exploration (Gressgard, 2011).

Recognition/Identification (SK4.5): The recognition or identification process is to know what is important for the organisation and is the fundamental building block in the production of organisational policy/strategy/vision. This process provides the organisation with a clear understanding of the desired future (where were yesterday, where they are today, and where they intend to be tomorrow), and with the ability to identify the specific sectors of the organisation where improvements may be needed (Misuraca et al., 2010).

\section{IT Sharability/ Interoperability (KI5)}

The organisation's capability to communicate, execute programs, or transfer data among various functional units in a manner that requires the user to have little or no knowledge of the unique characteristics of those units. This can enhance collaboration with the supply chain by eliminating the geographic factor, improve transaction speed and accuracy, better decisionmaking through the most up-to-date data and a higher pace of IT development.

Access/Uptake (SK5.1): The uptake and trial of new technologies and be integrated and 'talking' with existing IT is essential for an organisation to maintain its business competitive advantage; where IT is seen as a core business driver (Lam et al., 2010). The most matured organisations are that whom prioritise IT sharabillity and interoperability as key business drivers in the organisation; an unprepared organisation continues in its daily routine and refuses to try new technology to fit into existing systems, and no knowledge of IT sharabillity/interoperability exists in the organisation.

Existing/Availability (SK5.2): Organisations with IT available $24 / 7 / 366$ as a pre-requisite, irrespective of geographical location and free from technical bugs would be considered a highly matured organisations in terms of availability. Mid-level maturity organisations have their employees free to use the system, but only within geographical boundaries and only inside the time-frame (work hours) of the organisation. Internal systems are technically sound and reliable, but there is no provision for help shall any users requires it.

Legal Framework (SK5/3): It is essential for the organisation to identify, analyse and develop the legal and regulatory framework for IT interoperability, to include issues such as open standards, interpretation of data across diverse architectures, data/information exchange, reuse and storage (Kog, 2010). Organisation that does not have any legal framework for IT but is aware of its legal obligation is seen as worst-case scenario. Advanced level maturity organisations enforce its IT legal framework to its stakeholders and supply chain, and all parties must comply before work is set in motion.

Skill/Knowledge (SK5.4): Organisational IT sharabillity and interoperability knowledge is essential to optimise and align corporate IT strategy (technical) with business needs (process). Often in 
the organisation, there are individual leaders or champions in either the IT technical domain, or the organisational business needs - individuals now must champion both domains (Rezgui et al., 2011).

Standards (SK5.5): Standards provide the common platform for data, information and intelligence to be interoperable and sharable within the organisation, and also with stakeholders and supply chain. According to Papazoglou and Ribbers (2006), interoperability requires standardisation in four dimensions - technology, syntax, semantics, and pragmatics; and Gottschalk (2009) describes interoperability in digital government in five maturity levels - computer, process, knowledge, value and goal.

\section{Framework Evaluation and Validation}

This new framework was evaluated and validated through the 'parallel-forms' reliability process to ensure credibility and confirmability of data collected from the Case Studies and framework content objectivity. 16 UK and international construction academics and practitioners were invited to provide feedback on the framework around the areas of: usability, clarity and simplicity of the framework; flexibility and elasticity of the framework; scoring system of the framework; writing style, design and interface and framework presentation; possible use of framework in their organisation; applicability for the construction industry; applicability in their county (international experts only); and finally, personal and professional comments on the framework. Feedback included:

- Inclusion of a glossary of terms for the user of the framework as some terms may be too technical, or the meaning may differ to different individuals.

- Based on the hardcopy, the design could be simplified - yes, the words are important but a good design will make it look interesting without reading.

- Framework score provided benchmarks for the various departments within the same organisation to compared against and achieve.

- Framework scope is too wide, and there is a need to target the right audience. The framework now lacks focus - it could be designed as a tool for Senior Management or Executives and use the results to formulate strategic vision and strategy for the organisation; or the research could also design the framework to be sector specific (eg. construction, engineering, oil and gas, etc.), or hierarchy specific (eg. executives, middle management, operations, etc.).

- The framework gave an interesting insight into the readiness of organisations to adopt IT. The questions remain, "Are we ready for today's technology? Is technology used to its full potential? Or is technology just a fashion accessory?".

Feedback from externals were brought into context and changes to the framework include interface redesigned and simplified; key Indicator is colour coded for identification purposes to simplify the usability of the framework, and to act as a content guide; short description on Key Indicator is written to present a short introduction to the topic area; Sub-Key Indicator headline are re-worded to provide a 
more accurate representation of the indicator; each Sub-Key Indicator maturity is given keywords to provide users with a 'one word' explanation of the Sub-Key Indicator, and an extended summary to represent the maturity of the Sub-Key Indicator (eg. hands-on, open door, filtered, restrictive, nonexistent); long and difficult to understand sentences and changed or removed; and IT jargons and construction terms changed or removed. The corrected KIs and SKs are presented in Table 6. Part of the completed ERiC Framework is shown in Figures 1, 2, 3 and 4.

[ insert Table 6]

[ Insert Figure 1]

[ Insert Figure 2]

[ Insert Figure 3]

[ Insert Figure 4]

\section{Discussion}

The $\mathrm{Cl}$ is continuing to operate in a fragmented but dynamic and highly competitive environment. In this respect, Senior Management and key decision makers can continually try to find new ways of driving forward their businesses. With unprecedented levels of technological change now increasingly being used as a means through which competitive advantage can be leveraged, this research aimed to determine the UK Cl's perception on how businesses will have to change, from the way they are currently doing business to a more direct, structured and proactive approach (if they are going to be in a strong position to leverage e-readiness opportunities in the future). The alarming increase of expensive IT failures is also added the fear - IT should be considered a partner, not a foe.

There is no single accurate definition for e-readiness as different groups describe it differently. The various differences in e-readiness definitions raised the question of 'what is the most accurate definition for e-readiness?' The answer to this question is an ongoing debate; reflecting that there is no complete literature definition for e-readiness. This research takes the position of e-readiness as 'a measure of the degree to which an organisation may be ready, prepared or willing to obtain benefits that arise from the digital economy'.

This framework has contributed towards the thinking and future direction of e-readiness within the UK $\mathrm{Cl}$. The industry remains to be fragmented, stubborn and paper-intensive - but the future will be going digital and the longer constructions shy away from IT or new technologies, their future will be subdued. More work can be done on: 
- Global e-readiness index - with the framework now completed, it was strongly suggested to create a global e-readiness index for construction organisations. There is no such index available at the moment. The framework can be transformed into an online version and distributed worldwide. This will also open various routes for data collection and attract Governmental participation. Moving forward, this index could be the benchmark between different industries or between practices in different countries.

- Sector specific - the framework could be further refined to incorporate factors from other sectors (eg. manufacturing, petrochemicals etc.). The concepts remain similar, but the changes in the language, industry specific jargon and samples could be aligned to the specific industry need. From a research perspective, this provides the opportunity to assess the disparity between different industries.

- Hierarchy or department specific - the framework could also be altered to fit the needs of the various hierarchy levels and the myriad of departments in the organisation. Future work could include an assessment for level of management in the organisation, where Senior Management takes a different assessment from the operatives. This will provide a gap assessment between the hierarchies in the organisation. Another option is to provide different department with different assessments, and this could also show gaps between the departments.

- Provocative and invigorating topic - it is at times confrontational, to ask an organisation or an individual 'are you ready?' The answer is always 'yes'. It is not until you get the individual to understand the concepts and insights of e-readiness, the answers may change to 'yes, I might have missed that' or 'that is something we have not thought about' or 'we are only now looking into this'. But before we could discuss the topic with the individual, the answer is always 'we are ready'.

\section{Conclusion}

This research, using a mixed methodology of case studies, observations and expert validation, proffers the critical success factors necessary for the assessment of e-readiness for UK SMEs building services providers to reap business efficiencies, growth and development associated with technology. The development of the framework is to enable users to implement the e-readiness framework based on the researched key indicators and sub-key indicators. To assist organisations to implement the framework, a scoring system is proposed to provide a quantifiable result and a standard benchmark. To achieve this, each sub-key indicator is given a five-level maturity based on the notion that a distinction could be made in regard to levels of maturity of organisations based on pre-set characteristics. The completed Final Framework consisted of 5 key indicators, 25 sub-key indicators and 125 sub-key indicators maturity statements and sample cases.

The product is the E-Readiness for Construction (ERiC) framework for SME building services providers, which enables construction organisations to quantify and measure organisational e-readiness from an organisation, technical and process perspective. During the research lifespan, it witnessed the 
construction boom at the start of the research and witnessed the bust of the industry towards the end of the research. This saw the shift in e-readiness thinking from complacent to essential tool needed now; and the shift in e-readiness practice from unnecessary to a significant practice to determine gaps for organisations. Again we ask, 'Are you e-ready?' 


\section{References}

Ahuja, V., Yang, J. and Shankar, R. (2010) "IT-enhanced communication protocols for building project management", Engineering, Construction and Architectural Management, 17(2), 159-179.

Amalia, M. and Nugroho, Y. (2011), "An innovation perspective of knowledge management in a multinational subsidiary", Journal of Knowledge Management, 15(1), 71-87.

Amoretti, F. (2007), "International Organizations ICTs Policies: E-Democracy and E-Government for Political Development", Review of Policy Research, 24(4), 331-344.

Anwyl (2017), The Decline of Building Contractors. http://www.anwylconstruction.co.uk/shortageconstruction-sector/ [Date accessed 12 October 2017].

Bacic, D. and Fadlalla, A. (2016), "Business information visualization intellectual contributions: An integrative framework of visualization capabilities and dimensions of visual intelligence", Decision Support Systems, $89,77-86$

Banke, J. (2017), Technology Readiness Levels Demystified, National Aeronautics and Space Administration (NASA), http://www.nasa.gov/topics/aeronautics/features/trl demystified.html [Date accessed 2 July 2017]

Banwell, H. (1964), Report of the Committee on the Placing and Management of Contracts for Building and Civil Engineering Work. HMSO, London, UK.

Bazzy, J.D. and Woehr, D.J. (2017), "Integrity, ego depletion, and the interactive impact on counterproductive behaviour", Personality and Individual Differences, 105, 124-128,

Berente, N., Vandenbosch, B. and Aubert, B. (2009), "Information flows and business process integration", Business Process Management Journal, 15(1), 119-141.

BIS (2013), UK Construction - An economic analysis of the sector, Department for Business Innovation and Skills, HKSO, London, UK.

Brewer, G and Gajendran, T. (2012), "Attitudes, behaviours and the transmission of cultural traits", Construction Innovation, 12(2), 198-215.

bridges.org (2017), E-readiness assessment: Who is Doing What and Where?, Cape Town, South Africa. http://www.bridges.org/files/active/0/ ereadiness whowhatwhere bridges.pdf [Date accessed 28 February 2017]

Briscoe, G., Dainty, A.R.J. and Millet, S. J. (2000), "The Impact of the Tax System on Self-employment in the British Construction Industry", International Journal of Manpower, 21(8), 596-613.

Cartelli, A. (2007), "ICT and knowledge construction: Towards new features for the socio-technical approach", The Learning Organization, 14(5), 436-449.

Demirkesen, S. and Ozorhon, B. (2017), "Impact of integration management on construction project management performance", International Journal of Project Management, 35(8), 1639-1654.

Egan, J. (1998), Rethinking Construction. Report form the Construction Task Force, Department of the Environment, Transport and Regions, HMSO, London, UK.

Emmerson, H. (1962), Studies of Problems before the Construction Industries, HMSO, London, UK.

Fairclough, J. (2002), Rethinking Construction Innovation and Research: A Review of Government R\&D Policies and Practices, Department of Transport Local Government Regions, HMSO, London, UK.

Fortune (2018), The Construction Industry Is Finally Embracing Technology, Fortune Megazine. http://fortune.com/2018/10/02/construction-industry-technology/ [Date accessed 10 October 2018].

Fox, D. (2011), "Factors in ontological uncertainty related to ICT innovations", International Journal of Managing Projects in Business, 4(1), 137-149.

Gambatese, J.A. and Hallowell, M. (2011), "Enabling and measuring innovation in the construction industry", Construction Management and Economics, 29(6), 553-567.

Gottschalk, F. (2009), "Maturity levels for interoperability in digital government", Government Information Quarterly, 26(1), 75-81.

Goulding, J. and Lou, E.C.W. Lou (2013), "E-readiness in construction: an incongruous paradigm of variables", Architectural Engineering and Design Management, 9(4), 265-280.

Gressgard, L.J. (2011), "Virtual team collaboration and innovation in organizations", Team Performance Management, 17(1/2), 102-119.

Hadjithoma-Garstka, C. (2011), "The role of the principal's leadership style in the implementation of ICT policy", British Journal of Educational Technology, 42 (2), 311-326. 
Halabi, A., Kenett, R.S. and Sacerdote, L. (2017), “Modeling the relationship between reliability assessment and risk predictors using Bayesian networks and a multiple logistic regression model", Quality Engineering, 113.

HM Government (2013), Construction 2025, HMSO, London, UK.

Hosseini, M.R., Martek, I., Zavadskas, E.K., Aibinu, A.A., Arashpour, M. and Chileshe, N. (2018), "Critical evaluation of off-site construction research: A Scientometric analysis", Automation in Construction, 87, 235-247.

Howell, D. (1999), "Builders get the Manufacturers", Professional Engineer, May 1999, 24-25.

Jamieson, D., Fettiplace, S., York, C. Lambourne, E., Braidford, P. and Stone, I. (2013), Large Businesses and SMEs: Exploring how SMEs interact with large businesses, ORC International, London, UK.

Khalfan, M.M.A., Anumba, C.J. and Carrillo, P.M. (2001), "Development of a readiness assessment model for concurrent engineering in construction", Benchmarking: An International Journal, 8(3), 223-239.

Kirchhoff, B. A. (1994), Entrepreneurship and Dynamic Capitalism: The Economics of Business Firm Formation and Growth, Praeger Press: Westport, CT, USA.

Kog, Y.C. (2010), "Legal Issues of Integrated Network for Construction and Real Estate Sector", Journal of Legal Affairs and Dispute Resolution in Engineering and Construction, 2(4), 228-235.

Lam, P.T.I., Wong, F.W.H. and Tse, K.T.C. (2010), "Effectiveness of ICT for Construction Information Exchange among Multidisciplinary Project Teams", Journal of Computing in Civil Engineering, ASCE, 24(4), 365-377.

Latham, M. (1994), Constructing the Team: Joint Review of Procurement and Contractual Arrangements in the UK Construction Industry, Department of the Environment, HMSO, London, UK.

Lee, Y-C., Chu, P-Y. and Tseng, H-L. (2011), "Corporate performance of ICT-enabled business process reengineering", Industrial Management and Data Systems, 111(5), 735-754.

Leenen, L., Modise, M. and Le Roux, W.H. (2009), "Model for peace support operations: an overview of the ICT and interoperability requirements", 4th International Conference on Information Warfare and Security, Cape Town, South Africa, 10-18.

Lou, E.C.W. and Alshawi, M. (2009), “Critical success factors for e-tendering implementation in construction collaborative environments: people and process issues", Journal of Information Technology in Construction, 14, 98-109.

Lou, E.C.W. and Goulding, J.S. (2010), "The pervasiveness of e-readiness in the global built environment arena", Journal of Systems and Information Technology, 12(3), 180-195.

Love, P.E.D., Teo, P., Davidson, M., Cumming, S. and Morrison, J. (2016), "Building absorptive capacity in an alliance: Process improvement through lessons learned" International Journal of Project Management, 34(7), 1123-1137.

Mansell, R. (2010) "The information society and ICT policy: A critique of the mainstream vision and an alternative research framework", Journal of Information, Communication and Ethics in Society,8(1),22-41.

Margherita, A. and Petti, C. (2010), "ICT-enabled and process-based change: an integrative roadmap", Business Process Management Journal, 16(3), 473-491.

Misuraca, G., Broster, D. and Centeno, C. (2010), “Envisioning digital Europe 2030: scenario design on ICT for governance and policy modelling", in Proceedings of the 4th International Conference on Theory and Practice of Electronic Governance (ICEGOV '10), ACM, New York, USA, 347-356.

Mulcahy, J.F. (1990), "Management of the Building Firm", Proceedings CIB 90, Joint Symposium on Building Economics and Construction Management, Sydney, Australia, 11-21.

Mullins, L. J. (1999), Management and Organisational Behaviour, 5th ed. Pearson Education, Harlow.

Murnieks, C.Y., Cardon, M.S., Sudek, R., White, T.D. and Brooks, W.T. (2016), "Drawn to the fire: The role of passion, tenacity and inspirational leadership in angel investing", Journal of Business Venturing, 31(4), 468-484.

NFB (2012), BIM: ready or not?, National Federation of Builders (NFB), Crawley, London, UK.

Olawumi, T.O. and Chan, D.W.M. (2018), "Identifying and prioritizing the benefits of integrating BIM and sustainability practices in construction projects: A Delphi survey of international experts", Sustainable Cities and Society, 40, 16-27.

Papazoglou, M.P. and Ribbers, P.M.A. (2006), E-business: Organizational and technical foundations, John Wiley \& Sons, West Sussex, UK.

Parida, A. and Kumar, U. (2006), "Maintenance performance measurement (MPM): issues and challenges", Journal of Quality in Maintenance Engineering, 12(3), 239-251.

Podolny, J.M., Khurana, R. and Marya Besharov, M. (2010), "Revisiting the Meaning of Leadership”, Harvard Business Review, January 2010, 14-20. 
Rainer, R.K. and Cegielski, C.G. (2011), Introduction to Information Systems: Enabling and Transforming Business, $3^{\text {rd }}$ Edition, John Wiley \& Sons, USA.

Randel, A.E., Galvin, B.M., Shore, L.M., Ehrhart, K.H., Chung, B.G., Dean, M.A. and Kedharnath, U. (2018), "Inclusive leadership: Realizing positive outcomes through belongingness and being valued for uniqueness", Human Resource Management Review, 28(2), 190-203.

Rezgui, Y., Boddy, S., Wetherill, M. and Cooper, G. (2011), “Past, present and future of information and knowledge sharing in the construction industry: Towards semantic service-based e-construction?", Computer-Aided Design, 43(5), 502-515.

Rhodes, C. (2014), The construction industry: statistics and policy, House of Commons Library, HMSO, London, UK.

Robbins, D.K., Pantuosco, L.J., Parker, D.F., Fuller, B.K. (2000), "An empirical assessment of the contribution of small business employment to US state economic performance", Small Business Economics, 15(4), 293302.

Ruikar, R., Anumba, C.J. and Carrillo, P.M. (2006), "VERDICT-An e-readiness assessment application for construction companies", Automation in Construction, 15, 98-110.

Salah, Y. (2003), IT Success and Evaluation: A General Practitioner Model, PhD Thesis, Research Institute for the Built Environment (BuHu), University of Salford, Greater Manchester, UK.

Samaranayake, P. (2009), “Business process integration, automation, and optimization in ERP: Integrated approach using enhanced process models", Business Process Management Journal, 15(4), 504-526.

Sarros, J.C., Cooper, B.K. and Santora, J.C. (2011), "Leadership vision, organizational culture, and support for innovation in not-for-profit and for-profit organizations", Leadership and Organization Development Journal, 32(3), 291-309

Sarshar, M., Haigh, R. and Amaratunga, D. (2004), "Improving project processes: best practice case study", Construction Innovation: Information, Process, Management, 4(2), 69-82.

Sexton, M. and Barrett, P. (2003), “Appropriate innovation in small construction firms", Construction Management and Economics, 21(6), 623-633.

Simon, E. (1944), The Placing and Management of Building Contracts. HMSO, London, UK.

Smith, J., Love, P.E.D. and Wyatt, R. (2001), "To Build or not to Build? Assessing the Strategic Needs of Construction Industry Clients and their Stakeholder", Structural Survey, 19(2), 121-132.

Succar, B. (2009), "Building information modelling framework: A research and delivery foundation for industry stakeholders", Automation in Construction, 18(3), 357-375.

Wong, A., Holmes S. and Schaper, M.T. (2018), "How do small business owners actually make their financial decisions? Understanding SME financial behaviour using a case-based approach", Small Enterprise Research, 25(1), 36-51.

Xia, N., Zou, P.X.W., Griffin, M.A., Wang, X. and Zhong, R. (2018), "Towards integrating construction risk management and stakeholder management: A systematic literature review and future research agendas", International Journal of Project Management, 36(5), 701-715. 
Table 1: Potential e-readiness critical success factors

\begin{tabular}{|c|c|c|}
\hline $\begin{array}{l}\text { Leadership and } \\
\text { Empowerment }\end{array}$ & $\begin{array}{l}\text { - Authoritarian } \\
\text { - Encourage } \\
\text { - Engage } \\
\text { - Foresight/Vision } \\
\text { - Improve }\end{array}$ & $\begin{array}{ll}\text { - } & \text { Inspire } \\
\text { - Instigate } \\
\text { - Integrity } \\
\text { - Involve } \\
\text { - } \text { Revelation }\end{array}$ \\
\hline $\begin{array}{l}\text { Change } \\
\text { Management }\end{array}$ & $\begin{array}{l}\text { - Business Process Reengineering } \\
\text { - Implementation } \\
\text { - Interaction } \\
\text { - Methods } \\
\text { - Patron/ Champion }\end{array}$ & $\begin{array}{l}\text { - People management } \\
\text { - Practice } \\
\text { - Revolution } \\
\text { - Strategy / Strategic framework } \\
\text { - Support / Executive Sponsorship }\end{array}$ \\
\hline $\begin{array}{l}\text { Business and } \\
\text { Information } \\
\text { Process }\end{array}$ & $\begin{array}{l}\text { - Access / Availability } \\
\text { - Assimilation } \\
\text { - Automation } \\
\text { - Data exchange / Integration } \\
\text { - Existent }\end{array}$ & $\begin{array}{l}\text { - External parties / Integration } \\
\text { - } \text { Guidelines } \\
\text { - Internal employees } \\
\text { - Reengineer } \\
\text { - Standards }\end{array}$ \\
\hline $\begin{array}{l}\text { Policy/ Strategy/ } \\
\text { Vision }\end{array}$ & $\begin{array}{l}\text { - Diffusion } \\
\text { - Dissemination } \\
\text { - Foresight } \\
\text { - Futurist } \\
\text { - Inspiration / Empowerment } \\
\end{array}$ & $\begin{array}{l}\text { - New technologies } \\
\text { - Organisation } \\
\text { - Outcome } \\
\text { - Recognition / Identification } \\
\text { - Strategy }\end{array}$ \\
\hline $\begin{array}{l}\text { IT Sharability / } \\
\text { Interoperability }\end{array}$ & $\begin{array}{l}\text { - Access / Uptake } \\
\text { - Agreement } \\
\text { - BIM/IFC } \\
\text { - Existing / Availability } \\
\text { - Information }\end{array}$ & $\begin{array}{l}\text { - Legal } \\
\text { - Open source } \\
\text { - Skill / Knowledge } \\
\text { - Standards } \\
\text { - Understanding }\end{array}$ \\
\hline
\end{tabular}


Table 2: Case study matrix of potential e-readiness sub-key indicators

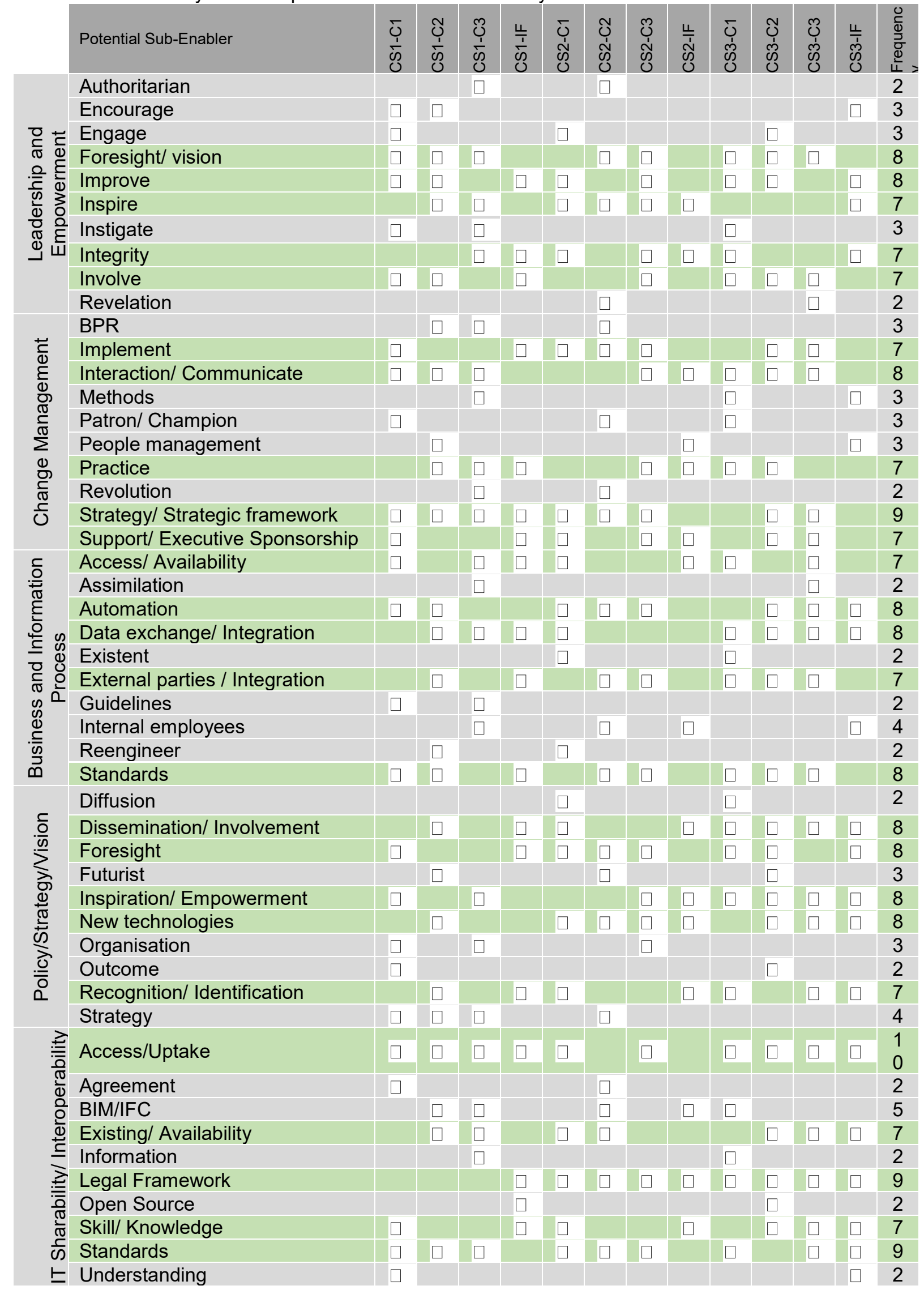




\begin{tabular}{|c|c|c|c|}
\hline $\begin{array}{c}\text { Key } \\
\text { Indicator }\end{array}$ & Case Study 1 & Case Study 2 & Case Study 3 \\
\hline 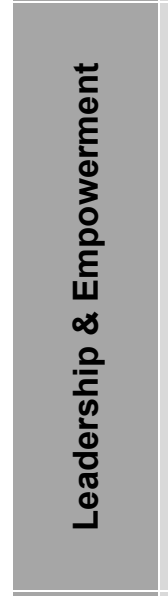 & $\begin{array}{l}\text { - Example to employee } \\
\text { - Grassroots problems } \\
\text { - Hands on } \\
\text { - Long term aim/vision } \\
\text { - Standard platform } \\
\text { - To staff, Division and organisation }\end{array}$ & $\begin{array}{l}\text { - } \text { Forward thinking } \\
\text { - Hands on } \\
\text { - } \text { IT for business expansion } \\
\text { - Keen interest } \\
\text { - Look up upon }\end{array}$ & $\begin{array}{l}\text { - Ability to inspire through example } \\
\text { - Acknowledge the need to continuously } \\
\text { improve } \\
\text { - Believe in The Board } \\
\text { - Bridge between client and internal } \\
\text { software/system } \\
\text { - Delivers on promises (so far) } \\
\text { - Great debater/speeches } \\
\text { - Inspiration with vision } \\
\text { - IT strategy written with staff } \\
\text { - Looking ahead but unsure what to do } \\
\text { - More said than done } \\
\text { - Staff empowerment } \\
\text { - Strategy lack of management support }\end{array}$ \\
\hline 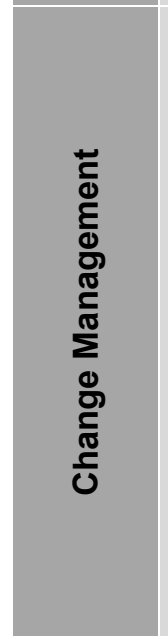 & $\begin{array}{l}\text { - Best practice } \\
\text { - Change management framework } \\
\text { - Culture } \\
\text { - Employee to process } \\
\text { - Lead by example } \\
\text { - Open to employee } \\
\text { - Push from top } \\
\text { - Staff buy-in }\end{array}$ & $\begin{array}{l}\text { - Ability to change as needed } \\
\text { - Change by example } \\
\text { - Change Champion } \\
\text { - Expectations } \\
\text { - Fluent in process change } \\
\text { - Leadership } \\
\text { - Manage change, perception \& } \\
\text { - } \text { Oxpectation } \\
\text { - } \text { Quality Assurance System (QAS) } \\
\text { - Senior Management \& employees open } \\
\text { - } \text { to change } \\
\text { - Whing new things } \\
\text { - Would be ideal is available }\end{array}$ & $\begin{array}{l}\text { - Bridge gap between site and } \mathrm{HQ} \\
\text { - } \text { Communication plan needed } \\
\text { - Need to get involve more } \\
\text { - Organisational strategy (integrated) } \\
\text { - Strategy + implementation plans } \\
\text { - Ttrategy available, not IT specific } \\
\text { The Board do not understand }\end{array}$ \\
\hline
\end{tabular}




\begin{tabular}{|c|c|c|c|}
\hline 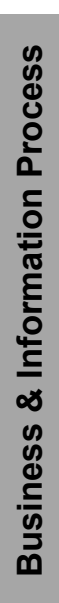 & $\begin{array}{l}\text { - Common standards } \\
\text { - No human error } \\
\text { - Increase efficiency } \\
\text { - Process integration } \\
\text { - Data interchange } \\
\text { - Standards }\end{array}$ & $\begin{array}{l}\text { - } 24 / 7 / 365 \\
\text { - Available worldwide via the Internet } \\
\text { - } \text { Business expansion } \\
\text { - } \text { Internal push, external pull } \\
\text { - Known flow } \\
\text { - Newn process } \\
\text { - Old software for data interchange } \\
\text { - Processes mapped } \\
\text { - } \text { QAS (common standard) } \\
\text { - QAS (known processes) } \\
\text { - QAS (staff knows who to approach) } \\
\text { - } \text { QAS (standards specified) } \\
\text { - Staff information interchange }\end{array}$ & $\begin{array}{l}\text { - Address gap between site and HQ } \\
\text { - Can be easily monitored } \\
\text { - International standards required } \\
\text { - Known business \& information process } \\
\text { - Staff to know where information/data is }\end{array}$ \\
\hline 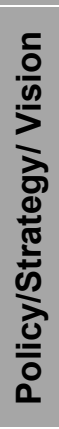 & $\begin{array}{l}\text { - Achieve more in the right direction } \\
\text { - Foresight } \\
\text { - Internal and external forces }\end{array}$ & $\begin{array}{l}\text { - Business and IT strategy aligned } \\
\text { - Business needs supporting through IT } \\
\text { - Inter-department appreciation } \\
\text { - Understand the organisation \& business } \\
\text { - Business foresight to predict future } \\
\text { technologies }\end{array}$ & $\begin{array}{l}\text { - Business strategy + IT strategy } \\
\text { - Identify the details } \\
\text { - Involve staff (experience, expertise, } \\
\text { - } \text { IT identified as strategic instrument } \\
\text { - Staff self-empower to learn IT } \\
\text { - To be more involved in organisation } \\
\text { - The Board recognise IT } \\
\text { - The Board unsure to invest, or not } \\
\text { - Staff \& The Board to try new things }\end{array}$ \\
\hline 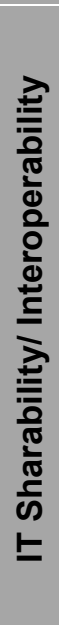 & $\begin{array}{l}\text { - Changing standards } \\
\text { - International standards } \\
\text { - New technologies } \\
\text { - Only now considered (BIM) } \\
\text { - Software to fit business } \\
\text { - Standard platform/dashboard } \\
\text { - Techie solutions } \\
\text { - Technical and process }\end{array}$ & $\begin{array}{l}\text { - Different systems (open system, } \\
\text { programming language) } \\
\text { - International partners. } \\
\text { - Lack of standards } \\
\text { - Seamless \& efficient with accurate } \\
\text { results } \\
\text { - Software integration }\end{array}$ & $\begin{array}{l}\text { - Data sensitivity } \\
\text { - Increased uptake } \\
\text { - Integrate software into single system } \\
\text { - Islands of automation } \\
\text { - kack of technical and academic } \\
\text { - Legality in sharing, exchanging and } \\
\text { - editing data } \\
\text { - Need to integrate internally } \\
\text { - No common international standard } \\
\text { - Numerous owners/provides with } \\
\text { - different ownership levels } \\
\text { - Single point for information capture \& } \\
\text { - Unkemination } \\
\text { Unn standards }\end{array}$ \\
\hline
\end{tabular}


Table 4: Tier 1 Key Indicator $(\mathrm{KI})$ default and variation scoring weightage

\begin{tabular}{|c|c|c|}
\hline Key Indicator & Default Weighting Option & Variation Weighting Option \\
\hline KI1 & $20 \%$ & $25 \%$ \\
\hline KI2 & $20 \%$ & $25 \%$ \\
\hline KI3 & $20 \%$ & $20 \%$ \\
\hline KI4 & $20 \%$ & $15 \%$ \\
\hline KI5 & $20 \%$ & $15 \%$ \\
\hline Total & $100 \%$ & $100 \%$ \\
\hline
\end{tabular}


Table 5: Tier 2 Sub Key Indicator (SK) default and variation scoring weightage

\begin{tabular}{|c|c|c|c|}
\hline $\begin{array}{c}\text { Sub-key } \\
\text { Indicator }\end{array}$ & $\begin{array}{c}\text { Default } \\
\text { Weighting }\end{array}$ & $\begin{array}{c}\text { Sub-key } \\
\text { Indicator }\end{array}$ & $\begin{array}{c}\text { Variation } \\
\text { Weighting }\end{array}$ \\
\hline SK1.1 & $4 \%$ & SK1.1 & $3 \%$ \\
\hline SK1.2 & $4 \%$ & SK1.2 & $4 \%$ \\
\hline SK1.3 & $4 \%$ & SK1.3 & $3 \%$ \\
\hline SK1.4 & $4 \%$ & SK1.4 & $3 \%$ \\
\hline SK1.5 & $4 \%$ & SK2.1 & $4 \%$ \\
\hline SK2.1 & $4 \%$ & SK2.2 & $7 \%$ \\
\hline SK2.2 & $4 \%$ & SK2.3 & $1 \%$ \\
\hline SK2.3 & $4 \%$ & SK2.4 & $3 \%$ \\
\hline SK2.4 & $4 \%$ & SK2.5 & $4 \%$ \\
\hline SK2.5 & $4 \%$ & SK3.1 & $5 \%$ \\
\hline SK3.1 & $4 \%$ & SK3.2 & $3 \%$ \\
\hline SK3.2 & $4 \%$ & SK3.3 & $5 \%$ \\
\hline SK3.3 & $4 \%$ & SK3.4 & $3 \%$ \\
\hline SK3.4 & $4 \%$ & SK3.5 & $5 \%$ \\
\hline SK3.5 & $4 \%$ & SK4.1 & $7 \%$ \\
\hline SK4.1 & $4 \%$ & SK4.2 & $4 \%$ \\
\hline SK4.2 & $4 \%$ & SK4.3 & $5 \%$ \\
\hline SK4.3 & $4 \%$ & SK4.4 & $5 \%$ \\
\hline SK4.4 & $4 \%$ & SK4.5 & $4 \%$ \\
\hline SK4.5 & $4 \%$ & SK5.1 & $8 \%$ \\
\hline SK5.1 & $4 \%$ & SK5.2 & $3 \%$ \\
\hline SK5.2 & $4 \%$ & SK5.3 & $4 \%$ \\
\hline SK5.3 & $4 \%$ & SK5.4 & $1 \%$ \\
\hline SK5.4 & $4 \%$ & SK5.5 & $4 \%$ \\
\hline SK5.5 & $4 \%$ & Total & $100 \%$ \\
\hline Total & $100 \%$ & & \\
\hline
\end{tabular}


Table 6: The final version of the key indicators (KI) and sub-key indicators (SK).

\begin{tabular}{|c|c|c|c|}
\hline \multicolumn{2}{|c|}{ Key Indicator (KI) } & \multicolumn{2}{|c|}{ Sub-Key Indicator (SK) } \\
\hline \multirow{5}{*}{$\mathrm{KI} 1$} & \multirow{5}{*}{ Leadership \& Empowerment } & SK1.1 & IT vision \\
\hline & & SK1.2 & Involvement \\
\hline & & SK1.3 & Inspiration \\
\hline & & SK1.4 & Integrity \\
\hline & & SK1.5 & Improvement \\
\hline \multirow{5}{*}{$\mathrm{KI} 2$} & \multirow{5}{*}{ Change Management } & SK2.1 & Strategic framework \\
\hline & & SK2.2 & Implementation \\
\hline & & SK2.3 & Executive sponsorship \\
\hline & & SK2.4 & Business practices \\
\hline & & SK2.5 & Communication \\
\hline \multirow{5}{*}{$\mathrm{KI} 3$} & \multirow{5}{*}{$\begin{array}{l}\text { Business \& Information } \\
\text { Process }\end{array}$} & SK3.1 & Standardisation \\
\hline & & SK3.2 & Automation \\
\hline & & SK3.3 & Availability \\
\hline & & SK3.4 & Integration \\
\hline & & SK3.5 & Interchange \\
\hline \multirow{5}{*}{$\mathrm{K} 14$} & \multirow{5}{*}{ Policy/Strategy/Vision } & SK4.1 & Collaboration \\
\hline & & SK4.2 & Identification \\
\hline & & SK4.3 & Dissemination \\
\hline & & SK4.4 & Empowerment \\
\hline & & SK4.5 & Future technologies \\
\hline \multirow{5}{*}{$\mathrm{KI} 5$} & \multirow{5}{*}{ IT Sharability/ Interoperability } & SK5.1 & Uptake \\
\hline & & SK5.2 & Standards \\
\hline & & SK5.3 & Availability \\
\hline & & SK5.4 & Knowledge \\
\hline & & SK5.5 & Legal framework \\
\hline
\end{tabular}


Figure 1: ERiC Framework summary interface

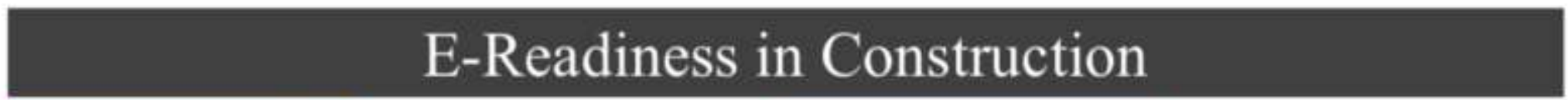

\begin{tabular}{|l|l|}
\hline Leadership \& \\
Empowerment \\
IT Vision \\
Involvement \\
Inspiration \\
Integrity \\
Improvernent \\
\hline Business \& \\
Information Process
\end{tabular}

\begin{tabular}{|c|c|c|c|}
\hline Change Management & Nere & \multirow{6}{*}{\multicolumn{2}{|c|}{ Training }} \\
\hline Strategic Framework & & & \\
\hline Implementation & & & \\
\hline Executive Sponsorship & & & \\
\hline Business Practices & & & \\
\hline Communication & & & \\
\hline Policy/Strategy/Vision & wore & \multirow{6}{*}{$\begin{array}{c}\text { Future } \\
\text { Tectusobogy } \\
\text { Empowenne. } \\
\text { nt }\end{array}$} & \\
\hline Collaboration & & & Identibcatie \\
\hline Identification & & & \\
\hline Dissemination & & & ieminati \\
\hline Empowerment & & & \\
\hline Future Technologies & & & \\
\hline
\end{tabular}


Figure 2: IT Vision (SK1.1) sub-key indicator within the ERiC framework.

Key Indicator

Maturity Level

Leadership \& Empowerment

\section{IT Vision}

The forward thinking

vision for technology to support and enhance

organisational aims in

terms of supporting the

administration,

management, employees

and the wider built

environment industry.

\begin{tabular}{|c|c|c|c|c|}
\hline Clohat engagement & National champines & Transformation & Obsolete and bolated & Nen-eaisteut \\
\hline $\begin{array}{l}\text { World-leader in providing } \\
\text { ideas, forward thinking and } \\
\text { continuous improvement. This } \\
\text { reflects extensive research and } \\
\text { development done within the } \\
\text { oryanisation, and often hailed } \\
\text { the as a global champion. }\end{array}$ & $\begin{array}{l}\text { Leading organisational } \\
\text { vision inline with } \\
\text { national/govemmental } \\
\text { strategies and policies, } \\
\text { with regards to the future } \\
\text { of IT. This level of } \\
\text { maturity, confidence and } \\
\text { forward thinking } \\
\text { demonstrates the current } \\
\text { and future needs of the } \\
\text { organisation and the } \\
\text { industry. }\end{array}$ & $\begin{array}{l}\text { Transfomation within } \\
\text { the otganisation is } \\
\text { apparent-people, } \\
\text { process and technology } \\
\text { from the myriad of } \\
\text { departments are } \\
\text { working/changing inline } \\
\text { with organisational II } \\
\text { vision. }\end{array}$ & $\begin{array}{l}\text { Much is talked about by } \\
\text { Top Management to } \\
\text { introduce, educate, re- } \\
\text { engineer and implement } \\
\text { IT-enabled practices in } \\
\text { the organisation; but } \\
\text { nothing is done. } \\
\text { Individual departments } \\
\text { within the organisation } \\
\text { are happy to work in } \\
\text { silos. }\end{array}$ & $\begin{array}{l}\text { Top Management has no } \\
\text { concem in improwing } \\
\text { current work practice } \\
\text { and or no interest joining } \\
\text { the digital economy - } \\
\text { maintaining a paper } \\
\text { intensive organisation. }\end{array}$ \\
\hline \multicolumn{5}{|l|}{ Example (E-tendering usage) } \\
\hline $\begin{array}{l}\text { Global use of e-tendering } \\
\text { solution for the organisation, } \\
\text { and enforcing e-tendering to } \\
\text { its sub-contractors and supply } \\
\text { chain. The organisation is able } \\
\text { to streamline and optimise } \\
\text { business practices with e- } \\
\text { tendering: and be in the } \\
\text { position to introduce new and } \\
\text { innovative tendering } \\
\text { procurement methods. }\end{array}$ & $\begin{array}{l}\text { Nation-wide use of e- } \\
\text { tendering within the } \\
\text { various departments of the } \\
\text { organisation - data is } \\
\text { shared within the } \\
\text { organisation in a single } \\
\text { country; the organisation is } \\
\text { now matured enough to } \\
\text { enforce e-tendering } \\
\text { through its sub-contractors } \\
\text { and national supply chain. }\end{array}$ & $\begin{array}{l}\text { Organisational-wide } \\
\text { implementation and } \\
\text { usage of e-tendering } \\
\text { system - tender } \\
\text { information and data is } \\
\text { shared by colleagues } \\
\text { within the locality of the } \\
\text { organisation. }\end{array}$ & $\begin{array}{l}\text { Only individual } \\
\text { departments (eg. } \\
\text { tendering department) in } \\
\text { the organisation are using } \\
\text { e-tendering; some } \\
\text { organisations are force } \\
\text { into using e-tendering by } \\
\text { prospective Clients. }\end{array}$ & $\begin{array}{l}\text { Organtisation maintains the } \\
\text { paper intensive traditional } \\
\text { (manual) tendering } \\
\text { methods, with no interest } \\
\text { and missing out on } \\
\text { existing e-tendering } \\
\text { opportunities. }\end{array}$ \\
\hline [Scoore] 5 & 4 & 3 & 2 & I \\
\hline
\end{tabular}


Figure 3 Strategic Framework (SK2.1) sub-key indicator within the ERiC framework.

Key Indicator

Maturity Level

Change Management

\section{Strategic Framework}

\begin{tabular}{|c|c|c|c|c|c|}
\hline \multirow{6}{*}{$\begin{array}{l}\text { A strategic framework } \\
\text { allows the organisation } \\
\text { and its supply chain to } \\
\text { create a roadmap for } \\
\text { change. This will drive the } \\
\text { change process from the } \\
\text { highest level (vision, goals } \\
\text { and objectives) to the day- } \\
\text { to-day work. }\end{array}$} & Adyanced & Competent & Transformatios & leolated & Non-evisteat \\
\hline & $\begin{array}{l}\text { The matured strategic } \\
\text { framework acts as a standard } \\
\text { for the organisation und its } \\
\text { stakeholders, enabling } \\
\text { continuous improvement. } \\
\text { adding to intellectual } \\
\text { property and increasing } \\
\text { competitive edge. }\end{array}$ & $\begin{array}{l}\text { Top Management } \\
\text { stablished an } \\
\text { organisational-wide } \\
\text { strategic framework for } \\
\text { change management as a } \\
\text { standard framework for all } \\
\text { departments - this } \\
\text { provides the vision and } \\
\text { awareness all employees } \\
\text { and organisational supply } \\
\text { chain. }\end{array}$ & $\begin{array}{l}\text { A standard IT change } \\
\text { management framework } \\
\text { is established and shared } \\
\text { between various } \\
\text { departments in the } \\
\text { organisation. Top } \\
\text { Management realises the } \\
\text { need for a change } \\
\text { management strategic } \\
\text { framework. }\end{array}$ & $\begin{array}{l}\text { Individual departments } \\
\text { create isolated } \\
\text { methodology for IT } \\
\text { change management, and } \\
\text { led by individual } \\
\text { employees. }\end{array}$ & $\begin{array}{l}\text { There is no strategic } \\
\text { framework for change } \\
\text { management in the } \\
\text { organisation, and there is } \\
\text { no intention of creating } \\
\text { one. }\end{array}$ \\
\hline & \multicolumn{5}{|c|}{ Example (Change management strategic framework for supply chain IT logisties integration) } \\
\hline & $\begin{array}{l}\text { The change management } \\
\text { framework provides a } \\
\text { platform for the organisation } \\
\text { and its supply chain to } \\
\text { implement If logistics and } \\
\text { the ability to share } \\
\text { construction logistics for the } \\
\text { project team and as } \\
\text { competitive tool in its global } \\
\text { business. }\end{array}$ & $\begin{array}{l}\text { The organisation put into } \\
\text { place its strategic } \\
\text { framework into practice- } \\
\text { this foresees a standard IT } \\
\text { logisties integration for its } \\
\text { departments and supply } \\
\text { chain to follow. }\end{array}$ & $\begin{array}{l}\text { Various departments } \\
\text { within the organisation } \\
\text { (eg. purchasing. } \\
\text { contracts, accounting) } \\
\text { share a common change } \\
\text { management framework } \\
\text { for change, and begin to } \\
\text { attract attention from } \\
\text { Top Management. }\end{array}$ & $\begin{array}{l}\text { The purchusing } \\
\text { department starts its own } \\
\text { change management } \\
\text { methods to try to } \\
\text { integrate IT practices } \\
\text { with its supply chain- } \\
\text { unknown to Top } \\
\text { Management. }\end{array}$ & $\begin{array}{l}\text { There is no change } \\
\text { management framework } \\
\text { for II logistics integration } \\
\text { for organisational supply } \\
\text { chain - all IT integration } \\
\text { is done at an ad-hoc basis. }\end{array}$ \\
\hline & [Sceore] 5 & 4 & 3 & 2 & $I$ \\
\hline & \multicolumn{5}{|l|}{ Notes } \\
\hline
\end{tabular}


Figure 4 Automation (SK3.2) sub-key indicator within the ERiC framework.

Key Indicator

Maturity Level

Business \& Information Process

\begin{tabular}{|c|c|c|c|c|c|}
\hline \multirow{6}{*}{$\begin{array}{l}\text { Automation illustrates the } \\
\text { degree of human } \\
\text { component that could be } \\
\text { removed from the } \\
\text { organisational business } \\
\text { and information processes. }\end{array}$} & Seimless & Advanced & Intermediate & Initiate & Non-retisteat \\
\hline & $\begin{array}{l}\text { Organisational business and } \\
\text { information-iutomated } \\
\text { processes are captured by } \\
\text { external stakeholders and } \\
\text { supply chain. This improves } \\
\text { the accuracy of the } \\
\text { information transferred and } \\
\text { ensures the repeatability of } \\
\text { the value-added tasks } \\
\text { performed. }\end{array}$ & $\begin{array}{l}\text { An organisational-wide } \\
\text { business and information } \\
\text { process automation is } \\
\text { implemented - this aims at } \\
\text { replacing human error and } \\
\text { resulting in the limitation } \\
\text { of mistakes, cost } \\
\text { reduction, transparency } \\
\text { and increased work } \\
\text { efficiency. }\end{array}$ & $\begin{array}{l}\text { Inter-department } \\
\text { business and information } \\
\text { processes are starting to } \\
\text { be automated, led by } \\
\text { department managers, } \\
\text { and Top Management } \\
\text { begins to take attention } \\
\text { to autornate processes. }\end{array}$ & $\begin{array}{l}\text { Individual department } \\
\text { begins to analyse, } \\
\text { document, optimise and } \\
\text { then automating business } \\
\text { processes for isolated } \\
\text { projects (often on an ad- } \\
\text { hoc basis) by a myriad of } \\
\text { methods and no vision } \\
\text { for the future. }\end{array}$ & $\begin{array}{l}\text { Work is completed } \\
\text { without technology } \\
\text { components to substitute } \\
\text { and or supplement manual } \\
\text { processes. }\end{array}$ \\
\hline & \multicolumn{5}{|c|}{ Example (Usage of construction estimatingtaking-off software) } \\
\hline & $\begin{array}{l}\text { All stakeholders and supply } \\
\text { chain within the project is } \\
\text { able to share and automate } \\
\text { processes. The shared } \\
\text { information provides } \\
\text { managers the ability to make } \\
\text { an accurate informed } \\
\text { decision, throughout the } \\
\text { project lifecycle. }\end{array}$ & $\begin{array}{l}\text { All departments in the } \\
\text { organisation shares and } \\
\text { obtain data from the } \\
\text { Tendering department. } \\
\text { This enables the } \\
\text { organisation to better share } \\
\text { resources, estimate } \\
\text { organisational budgets, } \\
\text { etc; reduces human error } \\
\text { and increases competence. }\end{array}$ & $\begin{array}{l}\text { The Purchasing. } \\
\text { Accounting and } \\
\text { Procuranent department } \\
\text { shares and obtain data } \\
\text { from the Tendering } \\
\text { department for project } \\
\text { costing, estimates and } \\
\text { contract preparation. }\end{array}$ & $\begin{array}{l}\text { The Tendering } \\
\text { department uses } \\
\text { estimating software to } \\
\text { compile quantities and } \\
\text { take-off directly from } \\
\text { drawings - cost estimates } \\
\text { ane prepared instantly. }\end{array}$ & $\begin{array}{l}\text { All quantities and taking } \\
\text { off are completed } \\
\text { manually, with the help of } \\
\text { a calculator. }\end{array}$ \\
\hline & [Scone] 5 & 4 & 3 & 2 & $t$ \\
\hline & Notes & & & & \\
\hline
\end{tabular}

